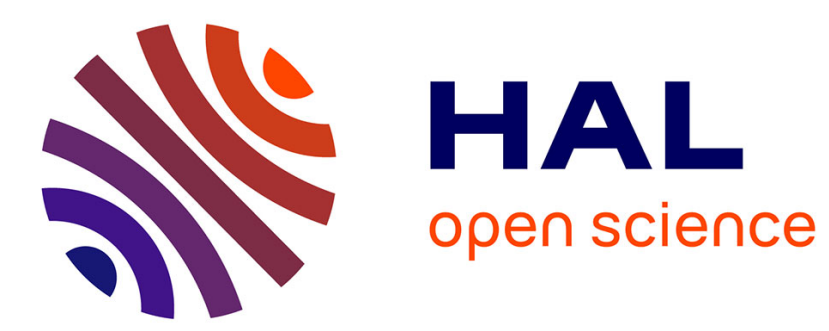

\title{
Mass Spectrometric Study of Copper(II) $\beta$-Diketonates Vapour Thermolysis Mechanism and Kinetics
}

\author{
A. Turgambaeva, A. Bykov, I. Igumenov
}

\section{To cite this version:}

A. Turgambaeva, A. Bykov, I. Igumenov. Mass Spectrometric Study of Copper(II) $\beta$-Diketonates Vapour Thermolysis Mechanism and Kinetics. Journal de Physique IV Proceedings, 1995, 05 (C5), pp.C5-221-C5-228. 10.1051/jphyscol:1995525 . jpa-00253850

\section{HAL Id: jpa-00253850 https://hal.science/jpa-00253850}

Submitted on 1 Jan 1995

HAL is a multi-disciplinary open access archive for the deposit and dissemination of scientific research documents, whether they are published or not. The documents may come from teaching and research institutions in France or abroad, or from public or private research centers.
L'archive ouverte pluridisciplinaire HAL, est destinée au dépôt et à la diffusion de documents scientifiques de niveau recherche, publiés ou non, émanant des établissements d'enseignement et de recherche français ou étrangers, des laboratoires publics ou privés. 


\title{
Mass Spectrometric Study of Copper(II) $\beta$-Diketonates Vapour Thermolysis Mechanism and Kinetics
}

\author{
A.E. Turgambaeva, A.F. Bykov and I.K. Igumenov \\ Institute of Inorganic Chemistry, Lavrentieva 3, Novosibirsk 630090, Russia
}

\begin{abstract}
Vapour thermolysis processes of copper(II) bis-chelate complexes with different $\beta$-diketones in the 160 $640^{\circ} \mathrm{C}$ temperature range were studied by using the high-temperature source of a molecular beam with mass spectrometric recording of the gas phase composition directly at the outlet from the thermal reactor. Schemes of a heterogeneous decomposition of these compounds vapour were suggested on the basis of temperature dependences of the thermolysis gaseous products composition. It was established that the mechanisms of thermal conversion of copper(II) complexes with fluorinated and non-fluorinated ligands were not similar. A comparison of the thermal behaviour of the complexes with fluorinated and non-fluorinated ligands in vacuum, hydrogen and oxygen was carried out. Effective values of kinetic parameters in the Arrhenius equation were calculated for the first-order reaction on initial compound from the temperature dependence of the rate constant. The sequence of copper(II) complexes with $\beta$-diketones having different end substituents according to the thermal stability was revealed from the values of the thermal decomposition activation energy.
\end{abstract}

\section{INTRODUCTION}

Metal $\beta$-diketonates owing to their relatively high volatility are widely applied as precursors in CVD. For the development of technological processes of deposition it is necessary to have the data not only on the volatility but also on the thermal stability and the thermolysis mechanism of the initial compound vapour

Copper(II) $\beta$-diketonates are used for the production of oxide and metal films [1]. Complexes of copper with $\beta$-diketones are of significant theoretical interest in addition to their practical implementation. They are convenient as a model object for the study of the thermolysis mechanism because, first, these complexes pass rather easily into the gas phase in a monomeric form, second, they form both a metal and an oxide solid phase.

To study the thermolysis mechanism of the substance vapour on the basis of the data about the gaseous products composition a mass spectrometric method is rather perspective as far as it permits to record gaseous products with a reliably high accuracy and selectivity especially at a low vapour pressure of the investigated compounds.

A number of copper(II) $\beta$-diketonates of the general formula $\mathrm{Cu}\left(\mathrm{R}^{1} \mathrm{C}(\mathrm{O}) \mathrm{CHC}(\mathrm{O}) \mathrm{R}^{2}\right)_{2} \quad($ Table 1$)$ thermolysis in vacuum, hydrogen and oxygen is investigated in the present paper. The influence of the end substituents $R^{1}$ and $R^{2}$ on the thermolysis mechanism is considered.

\section{EXPERIMENTAL}

To study the vapour thermolysis of the complexes we used a system based on the time-of-flight mass spectrometer MSKh-6 (USSR) with a special high-temperature molecular beam source. The experimental arrangement and procedure are detailed in [2] 
Table 1: Studied copper(II) $\beta$-diketonates

\begin{tabular}{|c|c|c|c|c|}
\hline \multirow[t]{2}{*}{ Name } & \multirow[t]{2}{*}{ Formula } & \multicolumn{2}{|c|}{ End substituents } & \multirow[t]{2}{*}{ Acronym } \\
\hline & & $\mathrm{R}^{\mathbf{l}}$ & $\mathbf{R}^{2}$ & \\
\hline Bis(acetylacetonato)copper(II) & $\mathrm{Cu}\left(\mathrm{C}_{5} \mathrm{H}_{7} \mathrm{O}_{2}\right)_{2}$ & $\mathrm{CH}_{3}$ & $\mathrm{CH}_{3}$ & $\mathrm{Cu}(\mathrm{aa})_{2}$ \\
\hline Bis(hexafluoracetylacetonato)copper(II) & $\mathrm{Cu}\left(\mathrm{C}_{5} \mathrm{HO}_{2} \mathrm{~F}_{6}\right)_{2}$ & $\mathrm{CF}_{3}$ & $\mathrm{CF}_{3}$ & $\mathrm{Cu}(\mathrm{hfa})_{2}$ \\
\hline Bis(dipivaloylmethanato)copper(II) & $\mathrm{Cu}\left(\mathrm{C}_{11} \mathrm{H}_{19} \mathrm{O}_{2}\right)_{2}$ & $\mathrm{C}\left(\mathrm{CH}_{3}\right)_{3}$ & $\mathrm{C}\left(\mathrm{CH}_{3}\right)_{3}$ & $\mathrm{Cu}(\mathrm{dpm})_{2}$ \\
\hline Bis(trifluoracetylacetonato)copper(II) & $\mathrm{Cu}\left(\mathrm{C}_{5} \mathrm{H}_{4} \mathrm{O}_{2} \mathrm{~F}_{3}\right)_{2}$ & $\mathrm{CF}_{3}$ & $\mathrm{CH}_{3}$ & $\mathrm{Cu}(\mathrm{tfa})_{2}$ \\
\hline Bis(pivaloyltrifluoracetonato)copper(II) & $\mathrm{Cu}\left(\mathrm{C}_{8} \mathrm{H}_{10} \mathrm{O}_{2} \mathrm{~F}_{3}\right)_{2}$ & $\mathrm{CF}_{3}$ & $\mathrm{C}\left(\mathrm{CH}_{3}\right)_{3}$ & $\mathrm{Cu}(\mathrm{pta})_{2}$ \\
\hline
\end{tabular}

The thermal conversion of the studied compound proceeded in the reactor whose walls had been coated with a film formed by the initial compound decomposition. It was necessary to ensure the reproducibility of the experimental data and to avoid the initial compound molecules exchange interactions with the material of the reactor.

The gas phase composition was recorded directly at the outlet from the reaction zone. It allowed to have information on primary products of the reaction. To obtain the temperature dependence of the ion peak intensities of the mass spectrum the reactor was heated linearly at a rate of $2.5 \mathrm{deg} / \mathrm{min}$.

The temperature in the evaporation zone and a temperature range at which the thermolysis was investigated were the following:

$$
\begin{array}{lll}
\mathrm{Cu}(\mathrm{aa})_{2}-150^{\circ} \mathrm{C}, 155-540^{\circ} \mathrm{C} ; & \mathrm{Cu}(\mathrm{dpm})_{2}-120^{\circ} \mathrm{C}, 150-600^{\circ} \mathrm{C} ; & \mathrm{Cu}(\mathrm{hfa})_{2}-50^{\circ} \mathrm{C}, 200-660^{\circ} \mathrm{C} ; \\
\mathrm{Cu}(\mathrm{tfa})_{2}-100^{\circ} \mathrm{C}, 190-640^{\circ} \mathrm{C} ; & \mathrm{Cu}(\mathrm{pta})_{2}-80^{\circ} \mathrm{C}, 190-640^{\circ} \mathrm{C} . &
\end{array}
$$

Hydrogen and oxygen were introduced into the system and mixed with the studied substance vapour before the inlet into the thermal reactor. The pressure in the analyzer of the mass spectrometer did not exceed $1 * 10^{-5}$ Torr.

\section{MASS SPECTRA OF COPPER(II) B-DIKETONATES}

The study of these compounds mass spectra and fragmentation patterns under an electron impact is not the subject of the present article, we only note that all the mass spectra were recorded at an ionizing electron energy of about $70 \mathrm{eV}$. Besides the molecular peak, the mass spectra of the complexes contain an abundant set of peaks of metal-containing ions. The mass spectra of $\mathrm{Cu}(\mathrm{aa})_{2}, \mathrm{Cu}(\mathrm{hfa})_{2}, \mathrm{Cu}(\mathrm{tfa})_{2}$ agreed satisfactorily with those reported in the literature [3].

For convenience, the most intensive metal-containing peak was chosen instead of a molecular ion to describe the behaviour of the complex at heating. The absence of the intensity disproportions of the metalcontaining ion peaks with the temperature growth is the evidence that the formation of the metalcontaining particles does not occur at the thermolysis since such a replacement seems sufficiently correct.

\section{RESULTS AND DISCUSSION}

\subsection{Thermolysis of $\mathrm{Cu}(\mathrm{aa})_{2}$ vapour}

Thermolysis of the $\mathrm{Cu}(\mathrm{aa})_{2}$ vapour as well as of the ligand (acetylacetone, Haa) in vacuum, hydrogen and oxygen was investigated in detail and described by us earlier [4]. It should be noted, that the radical particles are absent among the products of this complex decomposition. Ions with an even mass-to-charge ratio $(\mathrm{m} / \mathrm{z})$ alongside with fragmentary ones are present in the mass spectra recorded at high temperatures 
They are molecular ions of reaction products, such as acetylacetone, acetone, ketene, methylethylketone, carbon oxides, water, methane and $\mathrm{CH}_{3} \mathrm{C}(\mathrm{O}) \mathrm{CH}=\mathrm{CO}$.

The analysis of the temperature dependence of intensities of the ion peak corresponding to the thermolysis products allowed us to generalize the intramolecular character of the $\mathrm{Cu}(\mathrm{aa})_{2}$ thermal decomposition in vacuum. This process proceeds in three parallel directions depending on temperature:

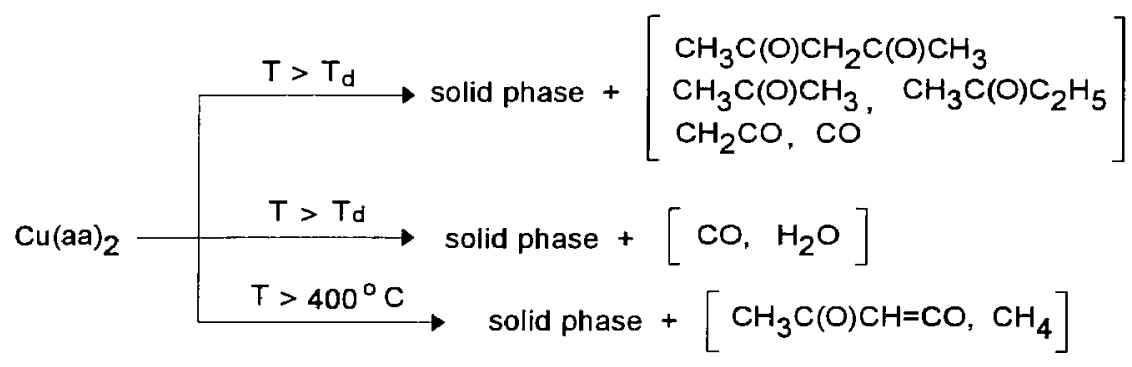

where $T_{d}=230 \cdot 10^{\circ} \mathrm{C}$ is the temperature of the thermolysis onset (so-called threshold temperature). In our experiments it is the temperature when a decrease in intensity of metal-containing ion peaks was observed. The values of the threshold temperature of the thermolysis of the studied complexes are listed in Table 2.

The absence of the ion peak with $\mathrm{m} / \mathrm{z} 99$ corresponding to the radical of the ligand $\mathrm{CH}_{3} \mathrm{C}(\mathrm{O}) \mathrm{CHC}(\mathrm{O}) \mathrm{CH}_{3} \cdot$ (aa') testifies that the compound decomposition by the scheme

$$
\mathrm{Cu}(\mathrm{aa})_{2} \longrightarrow \mathrm{Cu}(\mathrm{aa})^{\prime}+\mathrm{aa}^{\prime}, \mathrm{Cu}(\mathrm{aa})^{\prime} \longrightarrow \mathrm{Cu}+\mathrm{aa}^{\prime}
$$

offered in [5] does not occur. The already mentioned absence of the disproportion of the $\left[\mathrm{Cu}(\mathrm{aa})_{2}\right]^{+}$and $[\mathrm{Cu}(\mathrm{aa})]^{+}$intensities is another reason for the rejection of the given pattern of the thermal decomposition. The behaviour of these peaks testifies that $[\mathrm{Cu}(\mathrm{aa})]^{+}$results from the molecular ion fragmentation under the electron impact.

The thermolysis in the presence of hydrogen and oxygen proceeds similarly. However, in the latter case the thermal oxidative decomposition of reaction products (in particular, acetylacetone) is imposed on the thermolysis of the complex at a temperature above $300^{\circ} \mathrm{C}$. It results in an increase in the relative content of carbon oxides and water in comparison with the vacuum case. The thermolysis threshold temperature significantly (about $50^{\circ}$ ) increases in the presence of hydrogen. But no hydrogen influence on the gaseous products composition and thermolysis mechanism was observed.

\subsection{Thermolysis of $\mathrm{Cu}(\mathrm{hfa})_{2}$ vapour}

The temperature dependencies of the intensity of the ion peaks corresponding to the gaseous products of the $\mathrm{Cu}(\mathrm{hfa})_{2}$ thermolysis in vacuum are shown in Fig. 1a. A distinctive feature of this complex thermolysis is the prevalence of the particles with odd $\mathrm{m} / \mathrm{z}$ corresponding to the radical products of thermolysis and also to their fragments in the mass spectra recorded at high temperatures. The absence of these peaks in the mass spectra recorded at the ligand thermolysis also testifies that these peaks belong to thermolysis products. A formation of a radical of the ligand $\mathrm{CF}_{3} \mathrm{C}(\mathrm{O}) \mathrm{CHC}(\mathrm{O}) \mathrm{CF}_{3}$, as a product of reaction was not observed. We are sure that this fact is not caused by the experimental difficulties of this radical particle recording, since this particle was reliably recorded studying the $\mathrm{Pd}(\mathrm{hfa})_{2}$ thermolysis by a similar class device. 

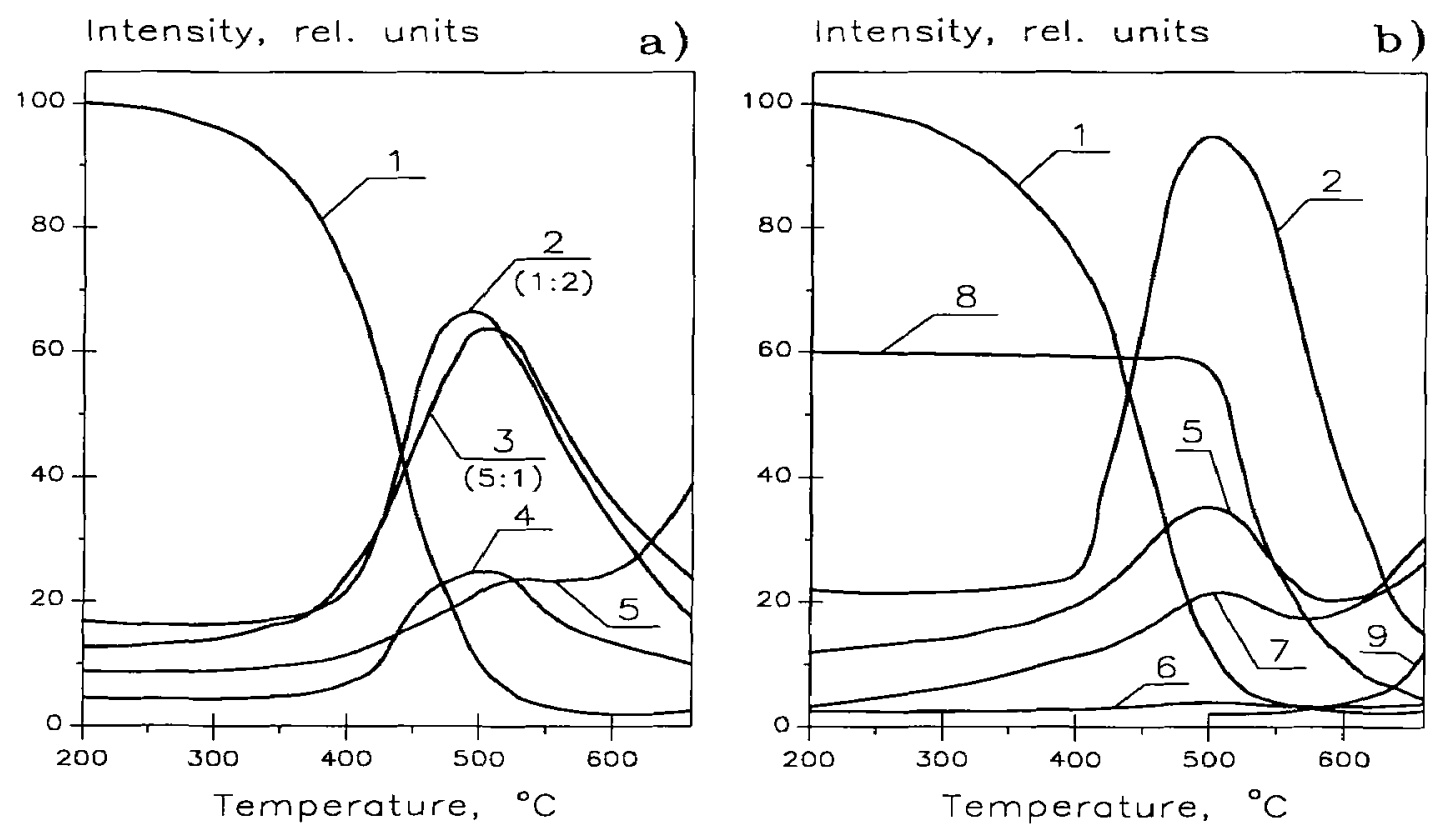

Figure 1: Temperature dependence of ion peak intensities corresponding to the main gaseous products of thermolysis of $\mathrm{Cu}(\mathrm{hfa})_{2}$ vapour in vacuum a) and in oxygen b): $\left[\mathrm{Cu}\left(\mathrm{CF}_{3} \mathrm{C}(\mathrm{O}) \mathrm{CHCO}\right]^{+}(1),\left[\mathrm{CF}_{3}\right]^{+}(2),\left[\mathrm{CF}_{2} \mathrm{C}(\mathrm{O}) \mathrm{CHCO}\right]^{+}(3),[\mathrm{CHCO}]^{+}\right.$ (4), $[\mathrm{CO}]^{+}(5),[\mathrm{HF}]^{+}(6),\left[\mathrm{CO}_{2}\right]^{+}(7),\left[\mathrm{O}_{2}\right]^{+}(8),\left[\mathrm{OCF}_{3}\right]^{+}(9)$.

On the basis of the obtained data it is possible to assume that the $\mathrm{Cu}(\mathrm{hfa})_{2}$ thermolysis proceeds at $\mathrm{T}>\mathrm{T}_{\mathrm{d}}$ with elimination of the radicals $\mathrm{CF}_{2} \mathrm{C}(\mathrm{O}) \mathrm{CH}=\mathrm{CO} \cdot \mathrm{CF}_{3}{ }^{\circ}, \mathrm{CHCO}$, as well as a carbon monoxide $\mathrm{CO}$ and a hydrogen fluoride $\mathrm{HF}$ in the gas phase. At higher temperatures $\left(>570^{\circ} \mathrm{C}\right)$, as it appears, another thermolysis rout is possible, that is the formation of the molecular products $\mathrm{CO}, \mathrm{CO}_{2}, \mathrm{HF}$. Simultaneously, a decomposition of the radicals formed at the first stage occurs. A S-shape of the temperature dependence of intensity of $[\mathrm{CO}]^{+}(\mathrm{m} / \mathrm{z} 28)$ indicates the formation of a carbon monoxide at different stages of the thermolysis. The process of the $\mathrm{Cu}(\mathrm{hfa})_{2}$ thermolysis can be presented by the following scheme:

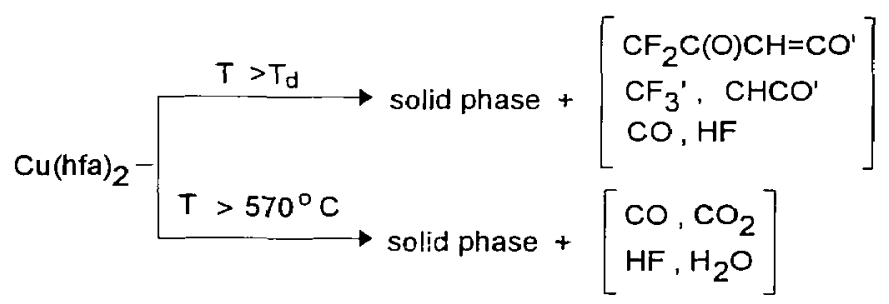

Such a quantitative and qualitative composition of gaseous procicts, in our opinion, testifies that the main part of the ligand remains as carbon-containing impurities in the solid phase.

A thermal decomposition of the complex in the presence of hydrogen proceeds in a similar way.

A study of the $\mathrm{Cu}(\mathrm{hfa})_{2}$ thermolysis in oxygen (Fig. lb) showed that no essential changes in the behaviour of the complex occur in comparison with that in vacuum. A significant $\mathrm{CO}_{2}$ and $\mathrm{OCF}_{3}$ content among the reaction products is observed owing to a deeper oxidation of carbon and $\mathrm{CF}_{3}$. It should also be noted that in this case a high-temperature stage of the reaction resulting in the formation of carbon oxides. $\mathrm{HF}$ and water owing to the thermal oxidative destruction of organic particles is more sharply defined 


\subsection{Thermolysis of $\mathrm{Cu}(\mathrm{tfa})_{2}$ vapour}

As this complex contains the ligand with different end substituents, i.e. occupies an intermediate position between $\mathrm{Cu}(\mathrm{aa})_{2}$ and $\mathrm{Cu}(\mathrm{hfa})_{2}$, it combines the peculiarities of the thermal behaviour of the both mentioned complexes.

The temperature dependencies of the intensity of ion peaks corresponding to the main gaseous thermolysis products in vacuum are shown in Fig. $2 \mathrm{a}$. The ratio between the radical $\left(\mathrm{CF}_{3}{ }^{*}, \mathrm{CHCO}^{*}\right)$ and molecular $\left(\mathrm{CO}, \mathrm{HF}, \mathrm{CH}_{3} \mathrm{C}(\mathrm{O}) \mathrm{CH}=\mathrm{CO}\right.$ ) products is most remarkable. In difference to $\mathrm{Cu}(\mathrm{hfa})_{2}$ an obvious quantitative prevalence of the radical particles is not observed here. Moreover, all these products are formed in the same temperature range, i.e. in this case there is no sharp division into high and low temperature stages.

No formation of new gaseous products at the thermolysis of the complex in hydrogen was observed. However, of interest is a significant in comparison with $\mathrm{Cu}(\mathrm{tfa})_{2}$ increase in the molecular products $\mathrm{HF}$, $\mathrm{CO}, \mathrm{CO}_{2}$ and $\mathrm{H}_{2} \mathrm{O}$ content (Fig. 2b).
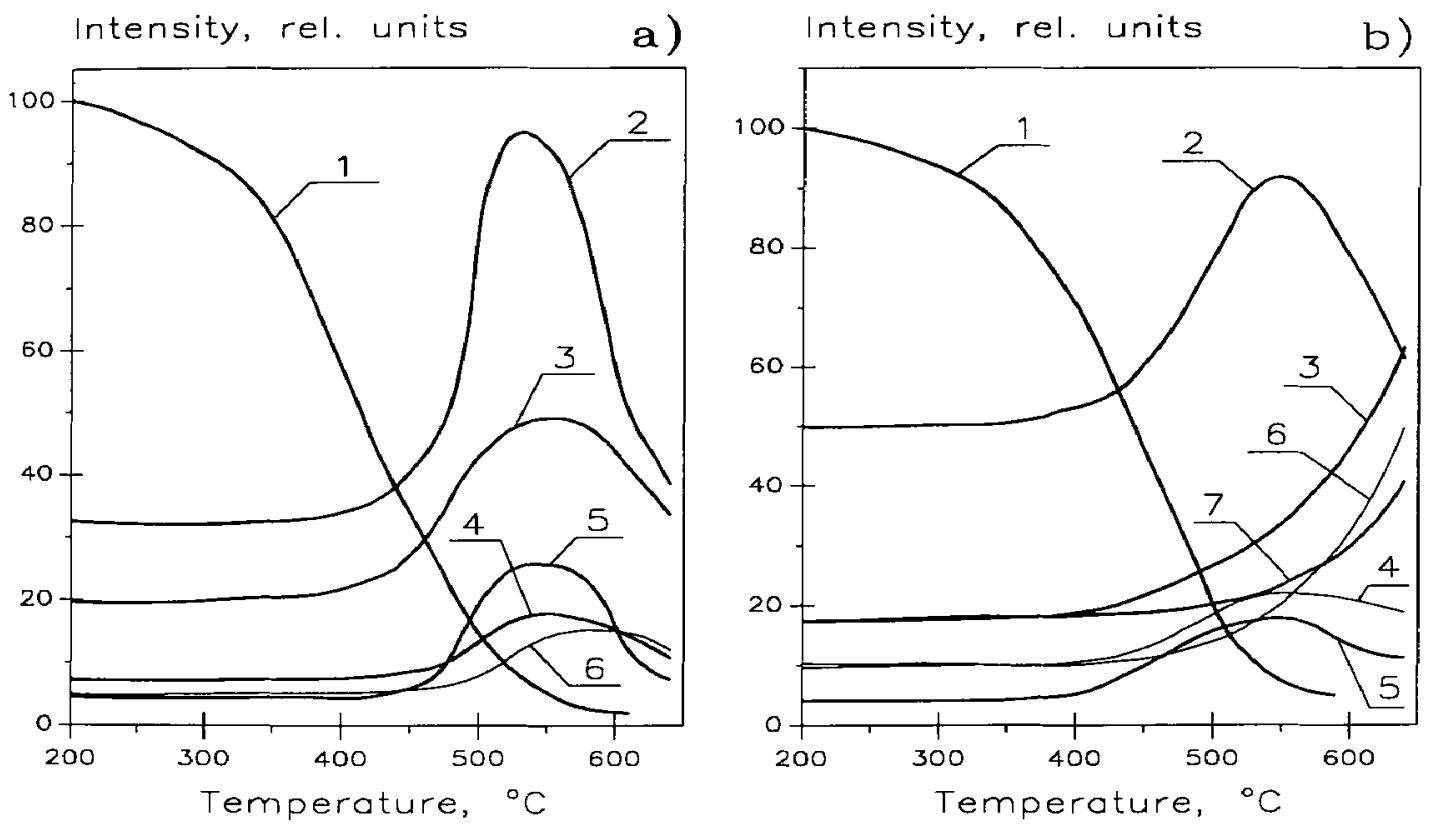

Figure 2: Temperature dependence of ion peak intensities corresponding to the main gaseous products of thermolysis of $\mathrm{Cu}(\mathrm{tfa})_{2}$ vapour in vacuum a) and in hydrogen b): $\left[\mathrm{Cu}\left(\mathrm{CH}_{3} \mathrm{C}(\mathrm{O}) \mathrm{CHCO}\right)\right]^{+}(1),\left[\mathrm{CF}_{3}\right]^{+}$(2), $[\mathrm{CO}]^{+}(3),[\mathrm{CHCO}]^{+}(4)$, $\left[\mathrm{CH}_{3} \mathrm{C}(\mathrm{O}) \mathrm{CHCO}\right]^{+}(5),[\mathrm{HF}]^{+}(6),\left[\mathrm{CO}_{2}\right]^{+}(7)$.

The analysis of the mass spectra recorded at different temperatures showed that there was no ligand (trifluoracetylacetone, $\mathrm{Htfa}$ ) and radical of the ligand ( $\left.\mathrm{tfa}^{\prime}\right)$ among the gaseous products. In this connection the possibility of an almost total regeneration of the ligand at the $\mathrm{Cu}(\mathrm{tfa})_{2}$ thermolysis in hydrogen reported in [5] is doubtful.

In the presence of oxygen a relative content of the molecular products increases. The particle $\mathrm{OCF}_{3}$, being the product of the $\mathrm{CF}_{3}$-group oxidation, appears at $\mathrm{T}>560^{\circ} \mathrm{C}$ 


\subsection{Thermolysis of $\mathrm{Cu}(\mathrm{dpm})_{2}$ vapour}

A study of the vapour thermolysis products of yet another non-fluorinated complex $\mathrm{Cu}(\mathrm{dpm})_{2}$ carried out by us earlier [2], showed that, as well as in the case of $\mathrm{Cu}(\mathrm{aa})_{2}$, the thermolysis of this complex proceeds in accordance with an intramolecular mechanism with liberating the ligand (dipivaloylmethane, Hdpm) as a product at $\mathrm{T}>330^{\circ} \mathrm{C}$. Simultaneously, a carbon monoxide $\mathrm{CO}$ and butane $\mathrm{C}_{4} \mathrm{H}_{10}$, which are products of decomposition of the remaining organic part of the complex, are liberated in the gas phase.

In the presence of oxygen a stage of the ligand formation is preserved but proceeds at a lower temperature in comparison with that in vacuum $\left(\mathrm{T}_{\mathrm{d}}\right.$ down to $300^{\circ} \mathrm{C}$ ). At a temperature above $340{ }^{\circ} \mathrm{C}$ oxygen oxidizes the formed ligand into carbon oxides and water. The decomposition temperature decreases depending on the concentration of oxygen in the thermal reactor, with a simultaneous appropriate increase in the thermolysis rate.

\subsection{Thermolysis of $\mathrm{Cu}(\mathrm{pta})_{2}$ vapour}

Temperature dependencies of the intensity of the ion peaks corresponding to the gaseous products of the $\mathrm{Cu}(\mathrm{pta})_{2}$ thermolysis in vacuum and in oxygen are shown in Fig. $3 \mathrm{a}$ and $3 \mathrm{~b}$ respectively.
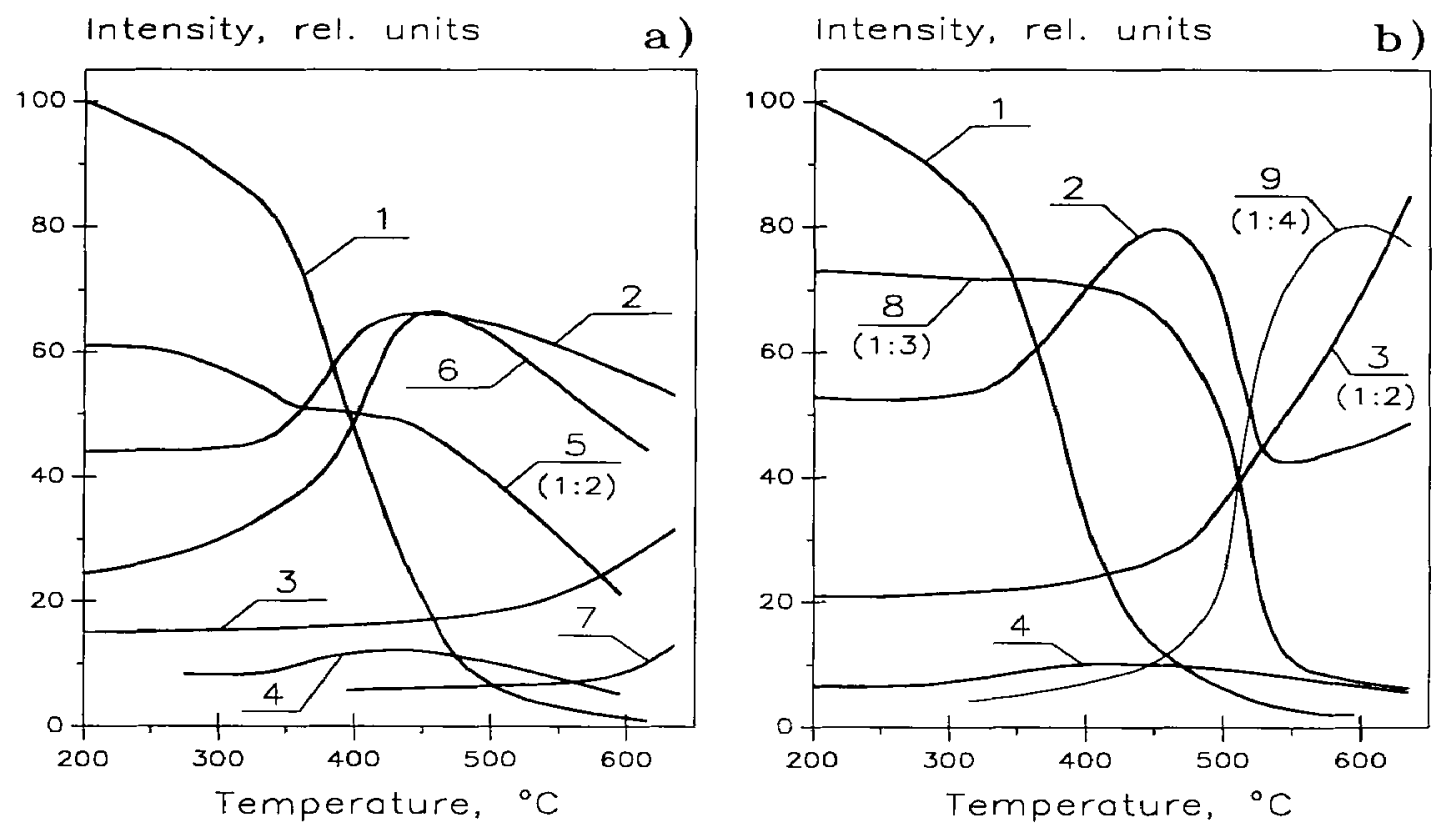

Figure 3: Temperature dependence of ion peak intensities corresponding to the main gaseous products of thermolysis of $\mathrm{Cu}(\text { pta })_{2}$ vapour in vacuum a) and in oxygen b): $\left.\left[\mathrm{Cu}_{(\mathrm{CF}} \mathrm{C}(\mathrm{O}) \mathrm{CHCO}\right)\right]^{+}(1),[\mathrm{CHCO}]^{+}(2),[\mathrm{CO}]^{+}(3)$. $\left[\mathrm{CF}_{3} \mathrm{C}(\mathrm{O}) \mathrm{CHC}\left(\mathrm{CH}_{3}\right)_{3}\right]^{+}(4),\left[\mathrm{C}\left(\mathrm{CH}_{3}\right)_{3}\right]^{+}(5),\left[\mathrm{CF}_{3}\right]^{+}(6),[\mathrm{HF}]^{+}(7),\left[\mathrm{O}_{2}\right]^{+}(8),\left[\mathrm{CO}_{2}\right]^{+}(9)$.

It should be noted that this complex, though contains a fluoromethyl group, largely resembles $\mathrm{Cu}(\mathrm{dpm})_{2}$. In particular, the thermolysis of this complex proceeds with liberating the ligand pivaloyltrifluoracetone (Hpta) (in Fig. 3 it is shown as a fragment with $\mathrm{m} / \mathrm{z}$ 168). It was not observed for other fluorinated complexes.

Analyzing the mass spectra of $\mathrm{Cu}(\mathrm{pta})_{2}$ recorded at different temperatures, three patterns of this complex thermal decomposition can be recognized. The first pattern is the intramolecular decomposition with forming the ligand $\mathrm{Hpta}$ and butane $\mathrm{C}_{4} \mathrm{H}_{10}$ as the main products. Another pattern results in the 
formation of the radical products $\mathrm{CF}_{3}, \mathrm{CHCO} \cdot$. Both these stages proceed practically in the same temperature range. The third thermolysis direction being possible at higher temperatures, leads to the formation of the elementary gaseous products, such us carbon oxides, hydrogen fluoride and water.

The thermolysis in the presence of hydrogen and oxygen proceeds in the same manner. As in the case of the above mentioned complexes, oxygen reacts with the decomposition products (at $\mathrm{T}>460^{\circ} \mathrm{C}$ ) producing significant quantities of $\mathrm{CO}, \mathrm{CO}_{2}, \mathrm{H}_{2} \mathrm{O}$.

\subsection{Kinetic parameters of copper(II) $\beta$-diketonates vapour thermolysis}

On the basis of the temperature dependence of the molecular ion intensity the rate constant for the firstorder reaction on an initial component was calculated by an empirical expression deduced from the equation of balance of initial component particles in the reactor (molecular current, absence of reverse reaction) [4].

The kinetic parameters in the Arrhenius equation (Table 2) were calculated from the temperature dependence of the reaction rate constant. These parameters correspond to a gross-process of the thermal decomposition of the initial compound.

Table 2: Threshold temperatures and effective values of kinetic parameters of the thermolysis of copper(II) $\beta$-diketonates

\begin{tabular}{|c|c|c|c|c|c|}
\hline Compound & Environment & $\begin{array}{l}\text { Threshold } \\
\text { temperature } \\
\mathrm{T}_{\mathrm{d}} \pm 10,{ }^{\circ} \mathrm{C}\end{array}$ & $\begin{array}{l}\text { Activation } \\
\text { energy } \\
E_{\mathrm{a}}, \mathrm{kJ} / \mathrm{mol}\end{array}$ & $\begin{array}{l}\text { Preexponen- } \\
\text { tial factor } \\
K_{0}, c^{-1}\end{array}$ & $\begin{array}{l}\text { Tempera- } \\
\text { ture range } \\
\Delta \mathrm{T},{ }^{\circ} \mathrm{C}\end{array}$ \\
\hline $\mathrm{Cu}(\mathrm{aa})_{2}$ & $\begin{array}{l}\text { vacuum } \\
\text { hydrogen } \\
\text { oxygen }\end{array}$ & $\begin{array}{l}230 \\
280 \\
235\end{array}$ & $\begin{array}{c}73.8 \pm 1.9 \\
133.0 \pm 12.4 \\
72.0 \pm 2.2\end{array}$ & $\begin{array}{l}1.1 * 10^{8} \\
1.2 * 10^{13} \\
7.2 * 10^{7}\end{array}$ & $\begin{array}{l}240-300 \\
285-305 \\
235-355\end{array}$ \\
\hline $\mathrm{Cu}(\mathrm{tfa})_{2}$ & $\begin{array}{l}\text { vacuum } \\
\text { hydrogen } \\
\text { oxygen }\end{array}$ & $\begin{array}{l}340 \\
345 \\
345 \\
\end{array}$ & $\begin{array}{l}105.1 \pm 1.4 \\
115.3 \pm 1.6 \\
146.7 \pm 3.3\end{array}$ & $\begin{array}{l}5.7 * 10^{8} \\
1.9 * 10^{9} \\
4.7 * 10^{11}\end{array}$ & $\begin{array}{l}380-530 \\
370-550 \\
370-510\end{array}$ \\
\hline $\mathrm{Cu}(\mathrm{hfa})_{2}$ & $\begin{array}{l}\text { vacuum } \\
\text { hydrogen } \\
\text { oxygen }\end{array}$ & $\begin{array}{l}350 \\
340 \\
360\end{array}$ & $\begin{array}{l}145.6 \pm 0.6 \\
143.2 \pm 0.7 \\
142.4 \pm 2.4\end{array}$ & $\begin{array}{l}4.0 * 10^{11} \\
4.0 * 10^{11} \\
1.8 * 10^{11}\end{array}$ & $\begin{array}{l}370-550 \\
350-540 \\
370-550\end{array}$ \\
\hline $\mathrm{Cu}(\mathrm{pta})_{2}$ & $\begin{array}{l}\text { vacuum } \\
\text { hydrogen } \\
\text { oxygen }\end{array}$ & $\begin{array}{l}345 \\
330 \\
330\end{array}$ & $\begin{array}{l}121.5 \pm 1.6 \\
109.3 \pm 1.8 \\
107.9 \pm 4.2\end{array}$ & $\begin{array}{l}1.5 * 10^{10} \\
1.5 * 10^{9} \\
2.5 * 10^{9}\end{array}$ & $\begin{array}{l}355-515 \\
350-510 \\
335-495\end{array}$ \\
\hline $\mathrm{Cu}(\mathrm{dpm})_{2}$ & $\begin{array}{l}\text { vacuum } \\
\text { oxygen }\end{array}$ & $\begin{array}{l}330 \\
300\end{array}$ & $\begin{array}{l}112.6 \pm 1.6 \\
137.0 \pm 3.1\end{array}$ & $\begin{array}{l}1.5 * 10^{9} \\
9.6 * 10^{11}\end{array}$ & $\begin{array}{l}360-510 \\
320-420\end{array}$ \\
\hline
\end{tabular}

It is necessary to note, that the listed in Table 2 values of the threshold temperature can be used as estimated parameters for only practical purposes. We do not assign any physical significance to these temperatures when discussing the thermolysis mechanism and thermal properties of the compounds.

It is more correct, from our viewpoint, to estimate the thermal stability of the complexes by values of the activation energy. However, it is necessary to take into account the distinction of the thermolysis mechanisms. Obtained from these data the sequence of the thermal stability of the copper(II) $\beta$-diketonates vapour is as follows:

$$
\mathrm{Cu}(\mathrm{aa})_{2}<\mathrm{Cu}(\mathrm{tfa})_{2}<\mathrm{Cu}(\mathrm{pta})_{2}<\mathrm{Cu}(\mathrm{dpm})_{2}<\mathrm{Cu}(\mathrm{hfa})_{2}
$$

i.e the thermal stability increases with introducing both electron-withdrawing $\mathrm{CF}_{3}$ and electron-releasing $\mathrm{C}\left(\mathrm{CH}_{3}\right)_{3}$ groups into acetylacetonate (Fig. 4). Omitting the details, it should be noted that the reasons for this in the two cases seemed to be different.

Note that the change of obtained values of the activation energy of the copper(II) B-diketonates thermolysis in vacuum has the same tendency as values of the energy of the homolytical breaking of the CL-O bond obtained from the themochemical study of the copper(II) p-diketonates [6] (Fig. 4). 


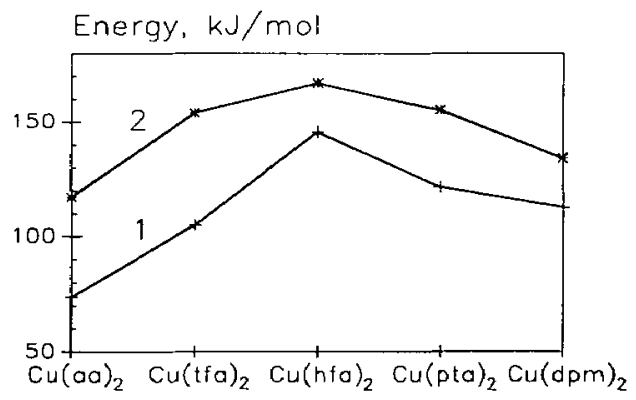

Figure 4: Activation energy (1) and energy of homolytical breaking of $\mathrm{Cu}-\mathrm{O}$ bond (2) for copper(II) $\beta$-diketonate complexes possessing various end substituents

\section{CONCLUSIONS}

The study of a number of copper(II) $\beta$-diketonates showed that the thermolysis mechanism for these complexes is determined by the end substituents in the ligand. The vapour thermolysis of the copper(II) complexes with $\beta$-diketones possessing hydrocarbon end substituents proceeds with the formation of only molecular products and along several routs depending on the temperature. The lower temperature stage corresponds to the liberation of the free ligand.

The thermolysis of the complexes of copper(II) with fluorinated ligands occurs due to the homolytical breaking of $\mathrm{C}-\mathrm{C}$ and $\mathrm{C}-\mathrm{O}$ bonds and results in the formation of radical particles as products. The formation of a free ligand, as well as a radical of the ligand, does not occur at the thermolysis of the fluorinated copper(II) complexes with the exception of $\mathrm{Cu}(\mathrm{pta})_{2}$.

It was established that both electron-withdrawing $\mathrm{CF}_{3}$ and electron-releasing $\mathrm{C}\left(\mathrm{CH}_{3}\right)_{3}$ substituents in the ligand increase the thermal stability of the copper(II) $\beta$-diketonates.

Regarding the production of films by CVD it is possible to note that:

- the thermolysis of the copper(II) $\beta$-diketonates in hydrogen does not result in the regeneration of the ligand and hence does not reduce the carbon content in the solid phase;

- the occurrence of bulky hydrocarbon substituents in the initial complex may cause a pollution of the formed solid phase by carbon due to the cracking of hydrocarbon products;

- the oxygen oxidizing the organic fragments into simple products promotes the formation of a more pure solid phase, however, in this case the metal may be oxidized;

- the use of the fluorinated complexes is limited by the higher temperatures of their decomposition in the processes where intermolecular interactions are absent.

\section{References}

[1] Laurie A.B. and Norton M.L., Mat. Res. Bull. 24 (1989) 213-219.

[2] Bykov A.F., Semyannikov P.P. and Igumenov I.K., J. Thermal Anal. 38 (1992) 1463-1475.

[3] Reichert C. and Westmore J.B., Can. J. Chem. 48 (1970) 3213-3221.

[4] Turgambaeva A.E., Bykov A.F. and Igumenov I.K., Thermochim. Acta, in press.

[5] Suvorova N., in: Films and coatings deposition by metalorganic compounds decomposition (Ed. by Razuvaev G.A., Nauka, Moscow, 1981) pp. 207-211 (in Russian).

[6] Fedotova N.E., Voityuk A.A., Bliznyuk A.A. and Igumenov I.K., Koord. Khim. 14 (1988) 1493-1506 (in Russian). 